\title{
Dielectric barrier discharge plasma-assisted catalytic reduction of NOx over Mn-Cu catalyst
}

\author{
Tao Wang ${ }^{1, ~ a, ~ H a n z i ~ L i u ̈, ~ b ~ a n d ~ B a o m i n ~ S u n ~}{ }^{3, c}$ \\ ${ }^{1}$ North China Electric Power University, Beijing 102206, China \\ ${ }^{2}$ North China Electric Power University, Beijing 102206, China \\ ${ }^{3}$ North China Electric Power University, Beijing 102206, China \\ awangtao0420@163.com, 'Ihzncepu@163.com, 'sbm@ncepu.edu.cn
}

Keywords: NO removal, Dielectric barrier discharge; $\mathrm{Mn}-\mathrm{Cu}$ catalyst

\begin{abstract}
Manganese-copper bimetal oxide catalysts supported on ZSM5 were produced by incipient wetness impregnation for selective catalytic reduction of NO with dielectric barrier discharge plasma. The significant enhanced activity of catalysts was exhibited with the increasing calcination temperature from $350^{\circ} \mathrm{C}$ to $550^{\circ} \mathrm{C}$, especially in the higher discharge power. NO removal efficiency reached $95 \%$ with the manganese-copper bimetal oxide catalyst of $550^{\circ} \mathrm{C}$ at $18 \mathrm{~W}$. The catalysts samples were characterized by XRD and BET. This results show that the $\mathrm{Cu}-$ Mn/ZSM-5 catalyst possesses more NO reduction activity with the adding calcination temperature.
\end{abstract}

\section{Introduction}

Emissions of Nitrogen oxides $\left(\mathrm{NO}_{\mathrm{x}}\right.$ ) from large quantities fuel combustion in power plants and cars have been one of the major problems that lead to the formation of acid rain and the precursor of ground level ozone. In the field of $\mathrm{NO}_{x}$ pollutants controlling, selective catalytic reduction (SCR) processes have been well used in power plant. However, problems like huge investment cost, high activation temperature of catalyst limit the applications of SCR. Recently, dielectric barrier discharge (DBD) combined with catalyst has been utilized for treatment of nitrogen oxides, CoOMS-2 calcined at $300^{\circ} \mathrm{C}$ [1], Ce-Ti at $500^{\circ} \mathrm{C}$ [2], $\mathrm{SG} / \gamma-\mathrm{Al}_{2} \mathrm{O}_{3}$ at $550^{\circ} \mathrm{C}$ [3] result in high $\mathrm{NO}$ removal efficiency. Herein, temperature is a mainly factor in nitrogen oxides removal. The experiment was carried out at different catalyst calcination temperature, investigating the discharge characteristics and NO removal.

\section{Experimental}

\section{Experimental Setup}

The schematic layout of the Mn-Cu/ZSM5 catalyst with plasma is presented in Fig.1. There are 500 ppm $\mathrm{NH}_{3}, 500 \mathrm{ppm}$ (parts per million) $\mathrm{NO}$ as the feeding gas composition and $6 \% \mathrm{O}_{2}$, and $\mathrm{N}_{2}$ as the carrier gas. The overall flow rate is $2 \mathrm{~L} / \mathrm{min}$ and gas hourly space velocity of $30000 \mathrm{~h}^{-1}$ in the dielectric barrier discharge reactor, separately. 
To maintain the designated gas temperature, we put the NO removal reactor into the furnace, the reactor contain two glass tubes with a height of $850 \mathrm{~mm}$ to form the dielectric barrier wall. The outer tube which cover with copper wire mesh had a diameter of $20 \mathrm{~mm}$ and a thicknesses of 1.5 $\mathrm{mm}$. The inner tube had a diameter of $5 \mathrm{~mm}$ and a thicknesses of $1 \mathrm{~mm}$.

\section{Catalyst preparation}

In the typical synthesis of Mn-Cu catalyst, incipient wetness impregnation of ZSM5 was used. In this step, $\mathrm{CuSO}_{4} \cdot 3 \mathrm{H}_{2} \mathrm{O}$ solutions was added to $\mathrm{Mn}\left(\mathrm{NO}_{3}\right)_{2}$ solutions, then put the mixed solutions through ultrasonic treatment for $2 \mathrm{~h}$, the mixture was dried at $110^{\circ} \mathrm{C}$ for $24 \mathrm{~h}$. The catalysts was calcined at $350^{\circ} \mathrm{C}, 450^{\circ} \mathrm{C}$ and $550^{\circ} \mathrm{C}$ for $4 \mathrm{~h}$, which owned the same $\mathrm{Cu}$ and $\mathrm{Mn}$ lodings : 12 wt. $\%$ $\mathrm{Cu}$ and 16 wt.\% Mn.

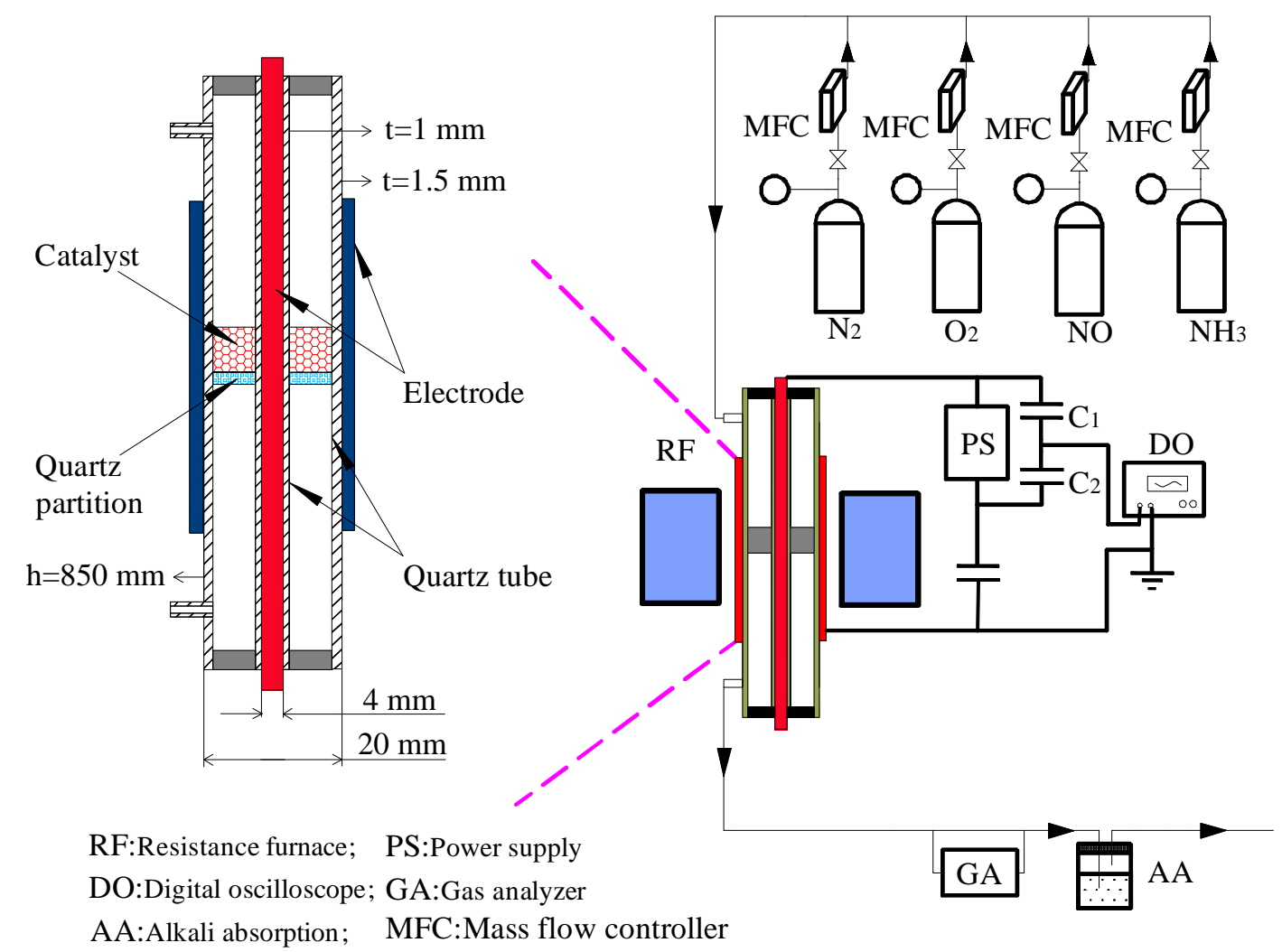

Fig. 1 Schematic of the DBD plasma experiment.

\section{Result and Discussion}

\section{NO removal by DBD combined with catalyst}

To examine the effects of temperature on NO removal, we adjusting the calcination temperature of catalyst at $350^{\circ} \mathrm{C}, 450^{\circ} \mathrm{C}, 550^{\circ} \mathrm{C}$ which is shown in Fig.2. For plasma without catalyst, a maximum NO conversion of approximately $50 \%$ was achieved at $18 \mathrm{~W}$. Whereas NO removal efficiency reached $95 \%$ with the manganese-copper bimetal oxide catalyst of $550^{\circ} \mathrm{C}$ at $18 \mathrm{~W}$, the result shows that the increased temperature has a evidently positive effect on NO removal efficiency. 
Moreover, the augment of plasma discharge power also promotes the NO removal efficiency. However, it exhibited little change in NO removal activities when the discharge is over 10W. In the dielectric barrier discharge reactor, The major pathway for NO removal are: [4,5]:

$$
\begin{gathered}
\mathrm{O}_{3}+\mathrm{NO} \rightarrow \mathrm{NO}_{2}+\mathrm{O}_{2} \\
\mathrm{O}+\mathrm{NO} \rightarrow \mathrm{NO}_{2}
\end{gathered}
$$

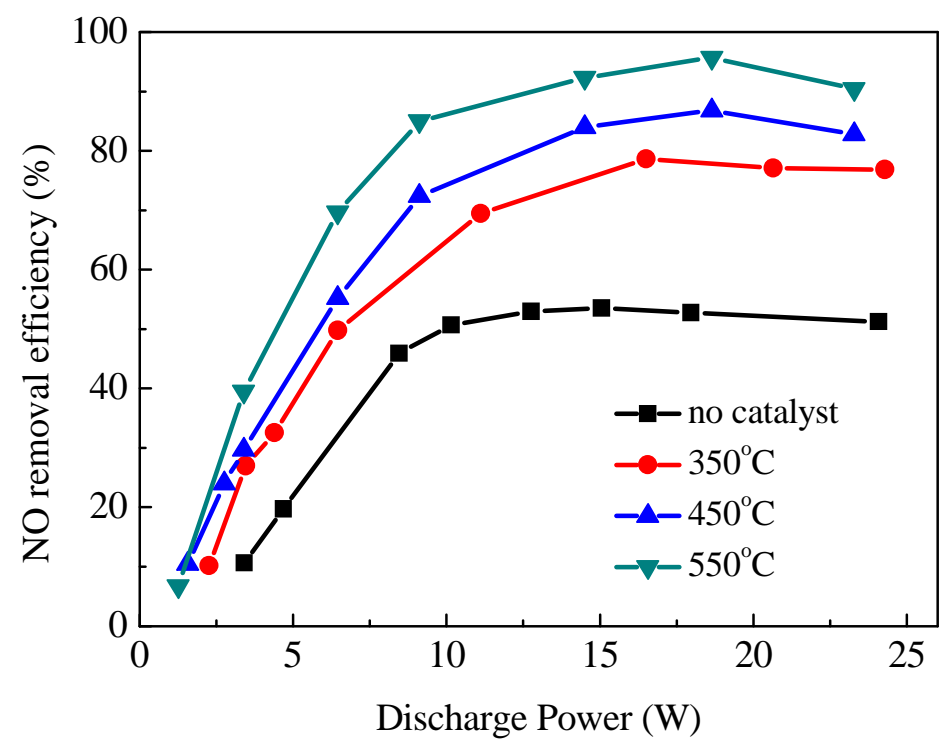

Fig.2 Effect of temperature and discharge power on NO removal efficiency

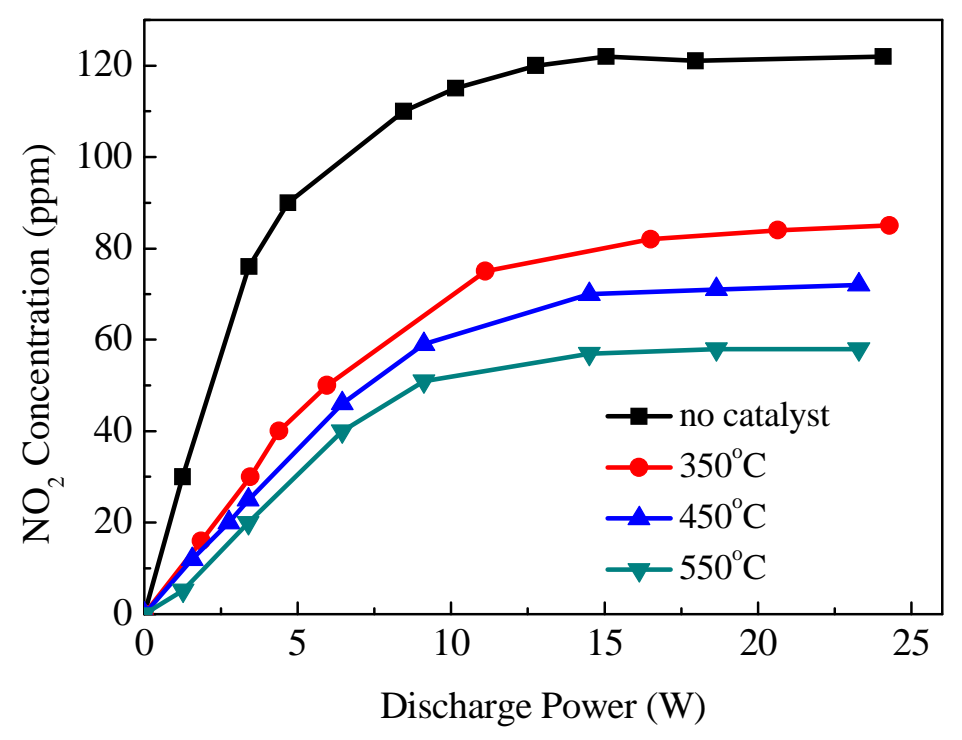

Fig.3 Effects of temperature on $\mathrm{NO}_{2}$ concentration 
The Fig. 3 has shown that the concentration of $\mathrm{NO}_{2}$ is around $120 \mathrm{ppm}$ with plasma alone but decreases to $58 \mathrm{ppm}$ with $\mathrm{Mn}-\mathrm{Cu} / \mathrm{ZSM} 5$ and temperature of $550^{\circ} \mathrm{C}$. Thus, Mn-Cu/ZSM5 evidently has a vital role in improving $\mathrm{NO}$ reduction. $\mathrm{NO}_{2}$ conversion efficiency was dramatic enhanced with the increasing temperature of catalyst. In this system, the catalytic reaction of NO removal with catalyst is $[6,7]$ :

$$
\begin{aligned}
& 4 \mathrm{NH}_{3}+4 \mathrm{NO}+\mathrm{O}_{2} \rightarrow 4 \mathrm{~N}_{2}+6 \mathrm{H}_{2} \mathrm{O} \\
& 4 \mathrm{NH}_{3}+2 \mathrm{NO}+2 \mathrm{NO}_{2} \rightarrow 4 \mathrm{~N}_{2}+6 \mathrm{H}_{2} \mathrm{O}
\end{aligned}
$$

When the temperature is under $200^{\circ} \mathrm{C}$, the fast SCR reaction (4) owns the leading role. With the existence of catalyst, $\mathrm{NO}_{2}$ is the key factors which reacts with $\mathrm{NH}_{3}$ and $\mathrm{NO}$ through (4) and can be decomposed through reactions (5) and (6) [8,9]:

$$
\begin{gathered}
\mathrm{NO}+\mathrm{NO}_{2}+2 \mathrm{NH}_{3} \rightarrow 2 \mathrm{~N}_{2}+3 \mathrm{H}_{2} \mathrm{O} \\
6 \mathrm{NO}_{2}+8 \mathrm{NH}_{3} \rightarrow 7 \mathrm{~N}_{2}+12 \mathrm{H}_{2} \mathrm{O}
\end{gathered}
$$

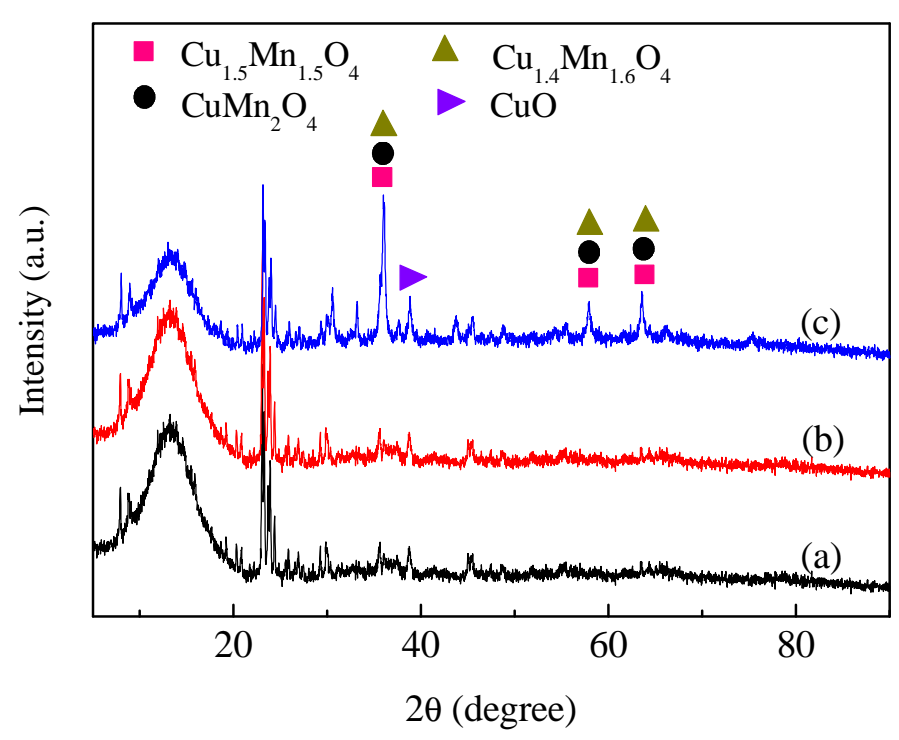

Fig.4 The XRD patterns of Mn-Cu/ZSM5 catalyst samples: (a) catalyst at $350^{\circ} \mathrm{C}$; (b) catalyst at $450^{\circ} \mathrm{C}$; (c) catalyst at $550^{\circ} \mathrm{C}$

The effect of NO removal will be influenced by calcination temperature, XRD patterns for Mn$\mathrm{Cu} / \mathrm{ZSM} 5$ catalyst samples calcined at $350^{\circ} \mathrm{C}, 450^{\circ} \mathrm{C}$ and $550^{\circ} \mathrm{C}$ are shown in Fig.4. The peak located at $38.8^{\circ}$ is the diffraction peak of $\mathrm{CuO}$. Mn-Cu/ZSM5 catalyst exhibited the typical peaks 
corresponding to ZSM-5. The peak located at $36.0^{\circ}, 57.9^{\circ}$ and $63.6^{\circ}$ is the diffraction peak of $\mathrm{Cu}_{1.5} \mathrm{Mn}_{1.5} \mathrm{O}_{4}$, The peak located at $36.0^{\circ}, 57.8^{\circ}$ and $63.5^{\circ}$ is the diffraction peak of $\mathrm{CuMn}_{2} \mathrm{O}_{4}$, The peak located at $36.0^{\circ}, 57.7^{\circ}$ and $63.4^{\circ}$ is the diffraction peak of $\mathrm{Cu}_{1.4} \mathrm{Mn}_{1.6} \mathrm{O}_{4}$. Those manganesecopper bimetal oxides appeared when the calcination temperature increases to $550^{\circ} \mathrm{C}$, which can obviously strengthen the activity of catalyst. Thus, the activity of Mn-Cu/ZSM5 catalyst is significantly enhanced with the temperature increase from $350^{\circ} \mathrm{C}$ to $550^{\circ} \mathrm{C}$.

Table. 1 Surface properties of catalyst

\begin{tabular}{cccc}
\hline Sample & BET surface area $\left(\mathrm{m}^{2} / \mathrm{g}\right)$ & Pore volume $\left(\mathrm{cm}^{3} / \mathrm{g}\right)$ & Pore diameter $(\mathrm{nm})$ \\
\hline $350^{\circ} \mathrm{C}$ & 228.8 & 0.125 & 2.2 \\
$450^{\circ} \mathrm{C}$ & 227.1 & 0.122 & 2.1 \\
$550^{\circ} \mathrm{C}$ & 209.1 & 0.108 & 2.1 \\
\hline
\end{tabular}

Table.1 shown that there is no significant change in the pore volume and pore diameter of Mn$\mathrm{Cu} / \mathrm{ZSM} 5$ catalyst samples with the temperature from $350^{\circ} \mathrm{C}$ to $550^{\circ} \mathrm{C}$. Meanwhile, the BET surface area is reducing with the increasing temperature of catalyst samples. However, BET surface area is not the mainly factor in NO removal [10].

\section{Conclusion}

Manganese-copper oxide catalysts supported on ZSM5 combined with dielectric barrier discharge (DBD) reactor for $\mathrm{NO}$ removal is calcined at $350^{\circ} \mathrm{C}, 450^{\circ} \mathrm{C}$ and $550^{\circ} \mathrm{C}$. The result of this experiment exhibited that $\mathrm{Cu}-\mathrm{Mn} / \mathrm{ZSM} 5$ catalysts calcined at $550^{\circ} \mathrm{C}$ owned best catalytic activity, the increased temperature of catalysts has an evidently positive effect on NO removal efficiency.

The dielectric barrier discharge technique combined with $\mathrm{Mn}-\mathrm{Cu}$ catalysts was used to enhance the catalytic activity in SCR reaction, which can promote a new method in SCR study work. On this basis, the paper mainly investigated the influence of different calcined temperature on catalysts activity, which can improve the efficiency of SCR reaction.

\section{Acknowledgment}

This study was supported by "the Fundamental Research Funds for the Central Universities (JB2015RCY06) and Key Projects in the National Science \& Technology of China (No. 2015BAA05B02). 


\section{References}

1. Li Y, Fan Z, Shi J, et al. Removal of Volatile Organic Compounds (VOCs) at Room Temperature Using Dielectric Barrier Discharge and Plasma-Catalysis[J]. Plasma Chemistry \& Plasma Processing, 2014, 34(4):801-810.

2. Ding J, Zhong Q, Zhang S. Simultaneous desulfurization and denitrification of flue gas by catalytic ozonation over Ce-Ti catalyst [J]. Fuel Processing Technology, 2014, 128:449-455.

3. Zhang H, Li K, Sun T, et al. Removal of styrene using dielectric barrier discharge plasmas combined with sol-gel prepared $\mathrm{TiO}_{2}$ coated $\gamma-\mathrm{Al}_{2} \mathrm{O}_{3}[\mathrm{~J}]$. Chemical Engineering Journal, 2014, 241:92-102.

4. Kim Y, Kang WS, Park JM, Hong SH, Song YH, Kim SJ (2004) IEEE Trans. Plasma Sci. 32: 1824.

5. Wang T, Sun B, Xiao H (2013) Plasma Chem. Plasma Process. 33: 307-322.

6. Wijayanti K, Andonova S, Kumar A, Li J, Kamasamudram K, Currier NW, Yezerets A, Olsson L (2015) Appl. Catal. B 166-167: 568-579.

7. Joshi SY, Kumar A, Luo J, Kamasamudram K, Currier NW, Yezerets A (2015) Appl. Catal. B 165: 27-35.

8. Ruggeri MP, Nova I, Tronconi E, Pihl JA, Toops TJ, Partridge WP (2015) Appl. Catal. B 166167: 181-192.

9. Koebel M, Madia G, Elsener M (2002) Catal. Today 73: 239-247.

10. Li Y, Fan Z, Shi J, et al. Removal of Volatile Organic Compounds (VOCs) at Room Temperature Using Dielectric Barrier Discharge and Plasma-Catalysis[J]. Plasma Chemistry \& Plasma Processing, 2014, 34(4):801-810. 